Research Article

\title{
Adverse Effect of Sublethal Concentrations of Insecticides on the Biological Parameters and Functional Response of Predatory Beetle Coccinella septempunctata (Coleoptera: Coccinellidae) of BrassicaAphid
}

\author{
Rahat Afza, Muhammad Asam Riaz*, Muhammad Afzal and Muhammad Zeeshan Majeed
}

Department of Entomology, College of Agriculture, University of Sargodha, Sargodha, Pakistan.

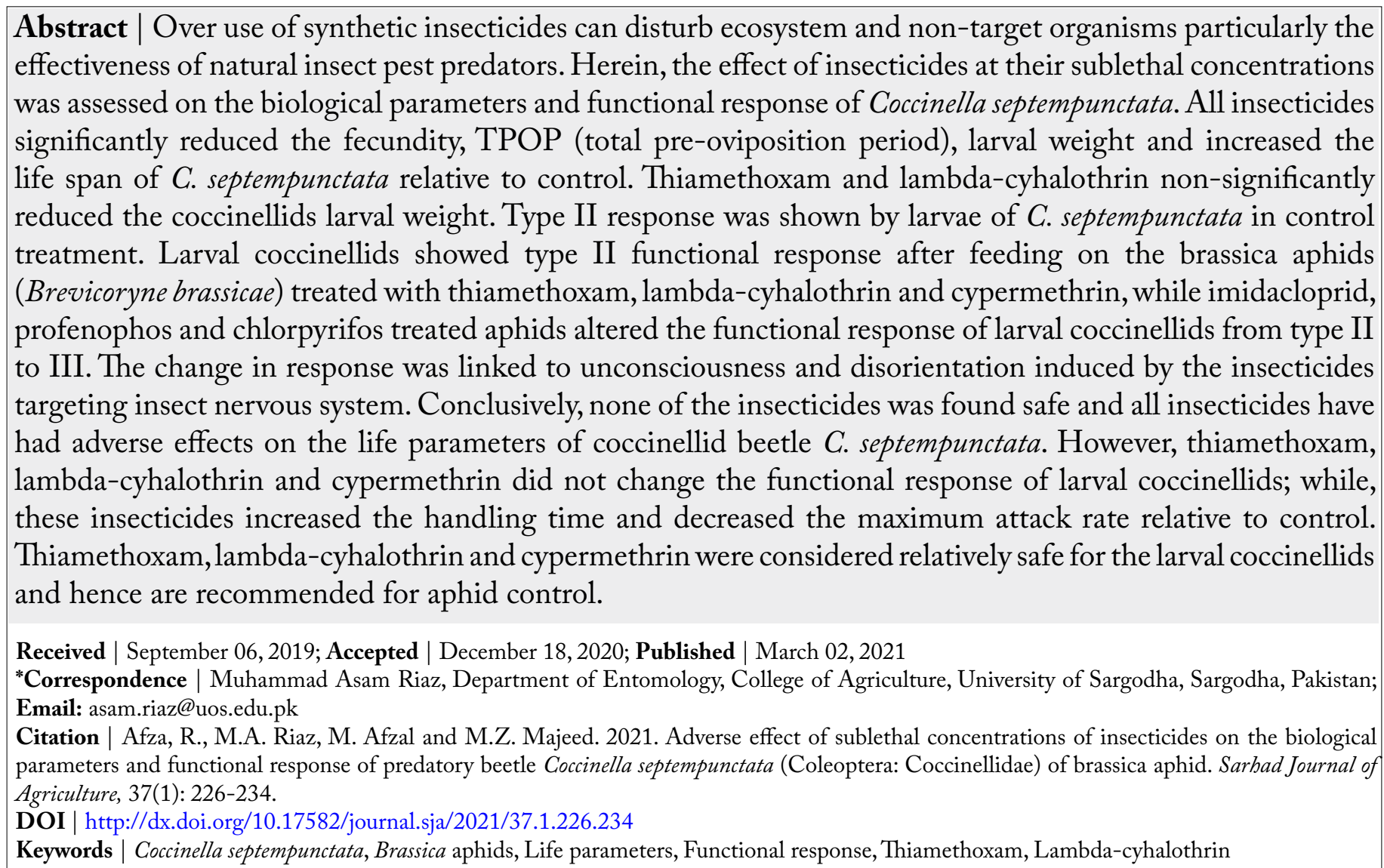

\section{Introduction}

$\mathrm{K}^{\mathrm{n}}$ nowledge about the side-effects of pesticides on growth, development and behavioral traits of biological control agents is very important for the optimal use of insecticides in a successful integrated pest management program (IPM). Therefore, understanding of lethal and sublethal effects of pesticides on the natural enemies is essential to better understand the effects of chemical insecticides on the biological components of the ecosystem (Tillman and Mulrooney, 2000; Sechser et al., 2003; Youn et al., 2003; Bozsik, 2006; Stark et al., 2007).

Coccinella septempunctata L (Coleoptera: Coccinellidae), commonly known as seven spotted lady beetle, is a common ladybird beetle that is widespread in natural and agricultural habitats (Yu et al., 2014). Larval 
and adult stages of beetle are polyphagous and predate Psylloidea, Aphidoidea, Coccoidea, mites and several other soft bodied arthropods (Dolling, 1991). It is a generalist and beneficial arthropod predator in many countries including China and Pakistan (Zhang et al., 2011; Saljoqi et al., 2012). Moreover, this species can easily be reared under laboratory conditions, making it an ideal test organism for studying the potential effects of lethal and sublethal doses of pesticides on natural enemies.

Aphids are severe pests of oilseed crops such as rapeseed, canola, sunflower and cotton in Pakistan (Farooq and Tasawer, 2008). Canola, Brassica napus, is receiving more prominence over all other Brassica species due to low erucic acid and glucosinolate contents (Khan and Begum, 2005). However, the use of insecticides on the canola crop to control pests is a common practice which affects the local population of coccinellids. Some beetles are susceptible to insecticides at recommended dose rate such as chlorpyrifos and pirmicarb. Generally, first and second instars of ladybeetles are more sensitive to thiamethoxam and abamectin, but these insecticides are effective against aphids. Several abilities of coccinellids such as fecundity, fertility or survival are inhibited and some time they reject to feed after exposure to insectcides (DeBach and Rosen, 1991). Due to scarcity of food and extreme repellency by the pesticides, beetles also dispersed themselves from the pesticides treated area (Newsom, 1974). Different pesticides have different ranges of toxicity and these beetles take on several behavioral and physiological changes to avoid these pesticides. Insecticides affect the physiology and behavior of coccinellids directly (Desneux et al., 2007). Physiological effects of insecticides extend from general biochemistry to neurophysiology, fecundity, development, immunology and sex ratio while behavioral effects include feeding behavior, oviposition, mobility, learning performance and orientation (Galvan et al., 2005; Desneux et al., 2007). Functional and numerical responses are the two main components of the predator-prey relationship used to suppress pest species (Holling, 1965). The relationship between the numbers of prey attacked by single predator at given time interval and prey density is called functional response (Martinou and Stavrinides, 2015), that is categorized into type I, type II and type III. Most of the natural enemies show type II and III. Functional response models are of great interest to IPM practitioners who traditionally tried to identify predators which have a positive densitydependent mortality rate (functional response Type III) because prey population is stabilized by such deaths (Murdoch et al., 2003). Usage of wide-range of insecticides frequently cause decline of numerous natural predators and also diminish the environment. In addition to lethal and sublethal effects, this also causes the pest population outbreaks (Hardin et al., 1995). Natural enemies' population and their performance can be improved if pesticides are selected carefully by keeping in mind their lethal and sub lethal effects (Desneux et al., 2005). The current research was aimed at determining the adverse effects of sublethal concentrations of insecticides on the biological parameters and functional response of larval coccinellids in order to make a rational decision to choose insecticide against brassica aphids.

\section{Materials and Methods}

\section{Rearing of coccinellids}

Adult beetles (C. septempunctata) were collected from the canola fields and released in pairs inside glass bowls set at appropriate temperature and relative humidity limitations $\left(26 \pm 1^{\circ} \mathrm{C}\right.$ and $65 \pm 5 \%$ R.H). Each bowl was covered with muslin cloth. Collected adults and newly hatched larvae were fed on natural diet i.e. aphids (Brevicoryne brassicae). Aphid infested twigs and branches were kept in each bowl to serve as food for larvae and adult predators and endowed with watersoaked cotton. The larvae and adults were provided with uncounted aphids per day. Adults were provided with glucose continuously as small droplets. Aphids were collected from different canola crop fields.

\section{Measurement of biological parameters after the application of sublethal concentrations of insecticides}

From the laboratory colonies of ladybeetle, three groups of hundreds eggs (0-6 hours old) were kept in a Petri dishes lined with moistened filter paper. For each treatment 100 eggs were used. All eggs were kept in growth chamber at $16: 8 \mathrm{~h}(\mathrm{~L}: \mathrm{D})$ and at $26 \pm 2^{\circ} \mathrm{C}$, $65 \pm 5 \%$ R.H. The eggs were inspected after every $6 \mathrm{~h}$ and newborn larvae were moved to new Petri dishes. All dishes were placed in an incubator at $26 \pm 2^{\circ} \mathrm{C}, 65 \pm$ 5\% R.H and 16:8 h (L: D) photoperiod. Aphids were supplied as a food source to beetles on daily basis.

Third instar (0-12 h old) larvae were treated topically using two sublethal concentrations $\left(\mathrm{LC}_{10}\right.$ and $\left.\mathrm{LC}_{30}\right)$ of insecticides (these concentrations were determined 
in preliminary experiments). We selected $3^{\text {rd }}$ instar larvae for the experiments due to their lower natural mortality compared to first two instars (Booth et al., 2007). Following parameters were studied to determine the long-term effects of insecticides on C. septempunctata lifespan, fecundity, total preoviposition period (TPOP) of females and weight of $4^{\text {th }}$ instars larvae. Hundred eggs were separated (three replications) from each treatment and control. These were kept in incubator until to record hatchability. TPOP is the duration from egg to first oviposition by the female. Larvae were provided with fresh prey daily until pupation. The data were analyzed using one-way ANOVA and means were compared by Tukey's HSD test with Minitab software. The significance level was $\mathrm{p}<0.05$.

Functional response of coccinellids after feeding on insecticides treated food

Individual adult and larval beetles were isolated without food for 24 hours. Foliage of canola was placed in petri-dishes $\left(150 \mathrm{~cm}^{2}\right.$ diameter $)$ and aphids were provided as food to each beetle. All petri dishes were lined with filter papers. Five aphid densities, viz. 20, 80, 160, 320, and 640 aphids, were used. Each density of prey was treated with sublethal concentration of insecticides $\left(\mathrm{LC}_{30}\right)$ and control (water). Twelve replications for each density were used and individual coccinellids were exposed to aphids for $24 \mathrm{~h}$. We recorded the number of preys that were consumed by each predator in every arena. One replication of each density was also used to determine mortality of aphids in the artificial environment in the absence of predators. Experiments were conducted in a growth chamber at $26 \pm 2^{\circ} \mathrm{C}, 65 \pm 5 \%$ R.H. and 16:8 h (L: D) photoperiod. Predation of aphids by adults was examined. Experimental procedure for examining larval coccinellids was identical to adults. Type of functional response and its parameters were determined using a two-step approach recommended by Juliano (2001).

Logistic regression was used to determine functional response as a proportion of aphids eaten as a function of initial prey density and the random predator equation was fitted for the determination of type of functional response. Logistic regression model was used to determine the shape by using the proportion of prey eaten $\left(\mathrm{Na} / \mathrm{N}_{\mathrm{o}}\right)$ as function of preys offered $\left(\mathrm{N}_{\mathrm{o}}\right)$ (Juliano, 2001). Hence the following polynomial equation was fitted on the data.
$\mathrm{Na} / \mathrm{No}=\exp (\mathrm{Po}+\mathrm{P} 1 \mathrm{No}+\mathrm{P} 2 \mathrm{~N} 22+\mathrm{P} 2 \mathrm{~N} 2 \mathrm{o}+\mathrm{P} 2 \mathrm{~N} 3 \mathrm{o}) / 1$ $+(\mathrm{Po}+\mathrm{P} 1 \mathrm{No}+\mathrm{P} 2 \mathrm{~N} 22+\mathrm{P} 2 \mathrm{~N} 2 \mathrm{o}$

$+\mathrm{P} 2 \mathrm{~N} 3 \mathrm{o}$

Where,

$\mathrm{N}_{\mathrm{a}}=$ the number of prey eaten; $\mathrm{N}_{\mathrm{o}}=$ the number of prey offered; $\mathrm{P}_{\mathrm{o}}=$ intercept $\mathrm{P}_{1}=$ linear coefficient; $\mathrm{P}_{2}=$ quadratic coefficient; $\mathrm{P}_{3}=$ cubic coefficient.

The function "glm" (in R software) was used to determine the coefficients of polynomial logistic regression. These parameters were estimated using the CAT MOD procedure. Maximum likelihood method was used to estimate the coefficients.

1. If the increased prey density and prey consumption rate have negative relationship (significant and negative linear parameter), for those data, the type II functional response was selected (Equation 4). In other words, type II functional response is described if $\mathrm{P}_{1}<0$, then the prey proportion consumed by predator decrease monotonically with the initially offered prey number.

2. If the increased prey density and prey consumption rate have positive relationship (significant and positive linear parameter), for those data, the type III functional response was selected (Equations 2, $3)$. In other words, type III functional response is described if $\mathrm{P}_{1}>0$ and $\mathrm{P}_{2}<0$, then the prey proportion consumed by predator increase with the initially offered prey number.

If the increased prey density and prey consumption rate have no relationship (linear parameter nonsignificant), for those data, the type I functional response was selected (Equation 5). In other words, the prey proportion consumed by predator doesn't depend upon the prey density. The data of the number of aphids consumed by coccinellids at different densities was analyzed by fitting Rogers' Type II Randon Predator Equation (Rogers, 1972) after determining the type of functional response.

Type II Random Predator Equation by Roger (Equation 2) is as followed;

$\mathrm{Na}=\mathrm{No}\{1-\exp [a(T h$ No $-\mathrm{T})]\} \quad \ldots .(2)$

Where,

$N a=$ no. of prey eaten; $N_{o}=$ no. of prey offered; $a=$ rate of attack; $T h=$ handling time; $T=$ time of confinement (24 hours). 
The coefficients of handling time and attack rate using non-linear least square regression as suggested by Rogers (1972) are used to determine the T. The function "nls" of R software was used.

For modeling the type III functional response, attack rate $(a)$ in (Equation 2) was substituted in (Equation 3) with a function of prey density (Zarghami et al., 2016). In the simplest generalized form, attack rate (Equation 3) is a function of the initial number of prey calculated as below.

$$
\mathrm{a}=\frac{(d+b N 0)}{(1+C N 0)}
$$

Where; $b, c$ and $d$ are constants that must be estimated. The simplest form arises when $a$ is a function of initial density, as shown below;

$\mathrm{Na}=\mathrm{N}_{0}\left\{1-\exp \left[\left(d+b \mathrm{~N}_{0}\right)(\mathrm{Th} \mathrm{Na}-\mathrm{T})\left(1-\mathrm{c} \mathrm{N}_{0}\right)\right]\right\}$

Equations 3 and 4 were used for the calculation of parameters of type III response.

The increase in the number of prey killed, in type I functional response, is linear and constant up to a maximum and then this number remain constant as the prey density further increases. A linear equation was used to estimate this response.

$$
\mathrm{Ne}=\alpha+13 \mathrm{~N}
$$

Where,

$\mathrm{Ne}=$ no. of prey eaten; $\mathrm{N}=$ prey density (no. of prey offered); $\alpha=$ intercept; $\beta=$ slope.

Type II functional response of larval beetle was described by Holling Disc equation. The estimates used for the equation were handling time (Th), search rate (a), predation rate $(\mathrm{T} / \mathrm{Th})$ and attack rate (a) of larval C. septempunctata after treatment of insecticides.

\section{Results and Discussion}

Aphids are notorious pests of oilseed crops (Yadav and Rathee, 2020) and coccinellids are very important biocontrol agent of aphids. Use of selective insecticides for the control of insect pests is an integral part of IPM (Tillman and Mulrooney, 2000; Stark et al., 2007). The objective of this study was to determine the effect of insecticides on larval coccinellids to sort out rational insecticide for IPM.

Effects on biological parameters after treating the aphids with sublethal concentrations of insecticides

The application of sublethal concentrations of imidacloprid, thiamethoxam, profenophos, chlorpyrifos, lambda cyhalothrin and cypermethrin significantly changed the life span, fecundity, TPOP, larval weight of $C$. septempunctata. However, profenophos, chlorpyrifos, lambda cyhalothrin and cypermethrin have non-significant effect on life span of coccinellids. Overall, the effect of $\mathrm{LC}_{30}$ was significantly different from those of $\mathrm{LC}_{10}$ and control (Table 1). Our results clearly indicate that all insecticides have adverse effect on life span, fecundity, TPOP and larval weight of C. septempunctata. While profenophos and chlorpyrifos and cypermethrin did not affect the life span of coccinellids. Thiamethoxam had no effect on larval weight. Overall, the response of coccinellids was concentration dependant. A growing body of literature demonstrates the sublethal effects of pesticides on many invertebrates (Widiarta et al., 2001; James, 2002; Pasqualini and Civolani, 2003; Capowiez and Berard, 2006; Lanzoni et al., 2012; Rahmani and Bandani, 2013; Tabozada et al., 2015; Fernandes et al., 2016; Sunday et al., 2016). Conclusively, these results clearly exhibit that sublethal concentrations of insecticides are harmful to predators such as coccinellids and can affect their life parameters, hence the predatory efficiency and pest management. None of the insecticides was found safe and all insecticides have negative effects on life parameters of coccinellids.

Effect on functional response after treating the aphids with sublethal concentrations of insecticides

The result of proportion of aphid consumption by $4^{\text {th }}$ instar $C$. septempunctata, is measured by logistic regression analysis (Table 2).

Larval coccinellids showed type II functional response. In type II functional response, prey consumption depends on prey density. In type III functional response, prey consumption keeps on increasing up to maximum and then become constant at sublethal concentration $\left(\mathrm{LC}_{30}\right)$, the insecticides thiamethoxam, cypermethrin and lambda-cyhalothrin showed type II response while rest of insecticides (imidacloprid, profenophos, chlorpyrifos) alter the type II response to type III (Table 2). 
Table 1: Effect of sub-lethal concentrations of insecticides on biological parameters of C. septempunctata.

\begin{tabular}{|c|c|c|c|c|c|}
\hline Insecticide & Concentration & Life span (days) & Fecundity & TPOP (days) & Larval weight \\
\hline \multirow[t]{5}{*}{ Imidacloprid } & $\mathrm{LC}_{10}$ & $74.4 \pm 0.3^{\mathrm{a}}$ & $561.7 \pm 3.8^{\mathrm{b}}$ & $9.4 \pm 0.3^{b}$ & $26.5 \pm 0.1^{\mathrm{b}}$ \\
\hline & $\mathrm{LC}_{30}$ & $76.1 \pm 0.4^{\mathrm{a}}$ & $536.1 \pm 2.3^{c}$ & $5.9 \pm 0.2^{\mathrm{c}}$ & $23.6 \pm 0.1^{\mathrm{c}}$ \\
\hline & Control & $72.1 \pm 0.6^{\mathrm{b}}$ & $737.8 \pm 2.6^{\mathrm{a}}$ & $10.8 \pm 0.4^{\mathrm{a}}$ & $28.8 \pm 0.2^{\mathrm{a}}$ \\
\hline & $\mathrm{P}$ & $0.00^{* *}$ & $0.003^{* *}$ & $0.0001^{* * * *}$ & $0.002^{* *}$ \\
\hline & $\mathrm{F}$ & 16.9 & 305.5 & 56.3 & 182.5 \\
\hline \multirow[t]{5}{*}{ Thiamethoxam } & $\mathrm{LC}_{10}$ & $73.3 \pm 0.8^{\mathrm{ab}}$ & $567.4 \pm 1.9^{\mathrm{b}}$ & $24.9 \pm 0.5^{b}$ & $33 \pm 0.3^{\mathrm{a}}$ \\
\hline & $\mathrm{LC}_{30}$ & $75.6 \pm 0.8^{a}$ & $541.6 \pm 1.3^{c}$ & $21.2 \pm 0.4^{\mathrm{c}}$ & $22.3 \pm 0.2^{\mathrm{b}}$ \\
\hline & Control & $71.5 \pm 0.7^{\mathrm{b}}$ & $745.3 \pm 1.7^{\mathrm{a}}$ & $31 \pm 0.4^{a}$ & $28.8 \pm 0.2^{\mathrm{a}}$ \\
\hline & $\mathrm{P}$ & $0.03^{*}$ & $0.004^{* *}$ & $0.0001^{* * * *}$ & $0.1^{\text {n.s }}$ \\
\hline & $\mathrm{F}$ & 6.1 & 305.5 & 95.8 & 2.1 \\
\hline \multirow[t]{5}{*}{ Profenophos } & $\mathrm{LC}_{10}$ & $75.7 \pm 0.3^{\mathrm{a}}$ & $573.0 \pm 2.01^{\mathrm{b}}$ & $25.6 \pm 0.5^{b}$ & $21.4 \pm 04^{b}$ \\
\hline & $\mathrm{LC}_{30}$ & $76.1 \pm 0.4^{a}$ & $547 \pm 0.3^{c}$ & $21.9 \pm 0.4^{c}$ & $19.1 \pm 0.2^{c}$ \\
\hline & Control & $72.8 \pm 0.9^{\mathrm{b}}$ & $752.7 \pm 0.7^{\mathrm{a}}$ & $31.9 \pm 0.4^{\mathrm{a}}$ & $28.8 \pm 0.2^{\mathrm{a}}$ \\
\hline & $\mathrm{P}$ & $0.00^{* *}$ & $0.002^{* *}$ & $0.002^{* *}$ & $0.002^{* *}$ \\
\hline & $\mathrm{F}$ & 17.9 & 305.5 & 95.3 & 271.08 \\
\hline \multirow[t]{5}{*}{ Chlorpyriphos } & $\mathrm{LC}_{10}$ & $76.5 \pm 2.7^{\mathrm{a}}$ & $624.1 \pm 2.8^{b}$ & $26.4 \pm 0.5^{\mathrm{b}}$ & $21.4 \pm 0.4^{\mathrm{b}}$ \\
\hline & $\mathrm{LC}_{30}$ & $77.1 \pm 0.6^{\mathrm{a}}$ & $595.7 \pm 1.7^{c}$ & $22.5 \pm 0.4^{c}$ & $19.1 \pm 0.2^{c}$ \\
\hline & Control & $72.3 \pm 2.3^{b}$ & $819.8 \pm 2.2^{\mathrm{a}}$ & $32.8 \pm 0.5^{a}$ & $28.8 \pm 0.2^{\mathrm{a}}$ \\
\hline & $\mathrm{P}$ & $0.02^{*}$ & $0.03^{*}$ & $0.003^{* *}$ & $0.0001^{* * * *}$ \\
\hline & $\mathrm{F}$ & 7.1 & 305.5 & 95.8 & 271.08 \\
\hline \multirow{5}{*}{$\begin{array}{l}\text { Lambda-cyhalo- } \\
\text { thrin }\end{array}$} & $\mathrm{LC}_{10}$ & $72.0 \pm 0.6^{\mathrm{b}}$ & $572.5 \pm 1.0^{\mathrm{b}}$ & $26.4 \pm 0.5^{b}$ & $28.7 \pm 0.9^{\mathrm{a}}$ \\
\hline & $\mathrm{LC}_{30}$ & $75.7 \pm 0.7^{\mathrm{a}}$ & $546.4 \pm 0.3^{c}$ & $22.5 \pm 0.4^{c}$ & $19.6 \pm 0.2^{\mathrm{b}}$ \\
\hline & Control & $72.3 \pm 1.2^{\mathrm{b}}$ & $752.0 \pm 0.7^{\mathrm{a}}$ & $32.8 \pm 0.5^{a}$ & $28.8 \pm 0.2^{\mathrm{a}}$ \\
\hline & $\mathrm{P}$ & $0.05^{*}$ & $0.03^{*}$ & $0.004^{* *}$ & $0.1^{\text {n.s }}$ \\
\hline & $\mathrm{F}$ & 5.1 & 305.5 & 95.8 & 2.02 \\
\hline \multirow[t]{5}{*}{ Cypermethrin } & $\mathrm{LC}_{10}$ & $72.4 \pm 0.8^{\mathrm{b}}$ & $558.3 \pm 7.5^{\mathrm{b}}$ & $21.9 \pm 0.6^{b}$ & $21.8 \pm 0.4^{b}$ \\
\hline & $\mathrm{LC}_{30}$ & $74.7 \pm 1.1^{\mathrm{a}}$ & $539.7 \pm 4.4^{\mathrm{b}}$ & $18.4 \pm 0.5^{\mathrm{c}}$ & $18.8 \pm 0.2^{c}$ \\
\hline & Control & $71.6 \pm 0.8^{b}$ & $742.9 \pm 4.9^{\mathrm{a}}$ & $29.2 \pm 0.4^{a}$ & $28.8 \pm 0.2^{\mathrm{a}}$ \\
\hline & $\mathrm{P}$ & $0.04^{*}$ & $0.003^{* *}$ & $0.0001^{* * * *}$ & $0.003^{* *}$ \\
\hline & $\mathrm{F}$ & 6.1 & 377.4 & 102.1 & 251.63 \\
\hline
\end{tabular}

ns: non-significant; ${ }^{*} P<0.05 ;{ }^{* * * 6} P<0.01 ;{ }^{* * 0 * 6} P<0.001$.

Table 2: Coefficients of the logistic regression analysis of the proportion of $L C_{30}$ treated aphids eaten by $4^{\text {th }}$ instar larvae of C. septempunctata.

$\begin{array}{llllll} & \text { Type } & \text { Intercept }\left(\mathbf{P}_{\mathbf{0}}\right) & \text { Linear }\left(\mathbf{P}_{\mathbf{1}}\right) & \text { Quadratic }\left(\mathbf{P}_{\mathbf{2}}\right) & \text { Cubic }\left(\mathbf{P}_{\mathbf{3}}\right) \\ \text { Control } & \text { II } & -0.31 \pm 0.05 & -3.52 \pm 0.23^{*} & 1.59 \pm 0.24 & -0.59 \pm 0.23 \\ \text { Imidacloprid } & \text { III } & -2.65 \pm 0.11 & 0.97 \pm 0.47^{*} & -0.33 \pm 0.50 & 0.43 \pm 0.45 \\ \text { Thiamethoxam } & \text { II } & -0.94 \pm 0.05 & -2.96 \pm 0.22^{*} & 1.69 \pm 0.24 & -0.81 \pm 0.24 \\ \text { Profenophos } & \text { III } & -2.26 \pm 0.08 & -0.24 \pm 0.34 & 0.57 \pm 0.37 & -0.16 \pm 0.36 \\ \text { Chlorpyriphos } & \text { III } & -2.65 \pm 0.11 & 0.97 \pm 0.47^{*} & -0.33 \pm 0.50 & 0.43 \pm 0.45 \\ \text { Lambda-cyhalothrin } & \text { II } & -1.32 \pm 0.05 & -2.25 \pm 0.23^{*} & 1.65 \pm 0.25 & -0.73 \pm 0.25 \\ \text { Cypermethrin } & \text { II } & -1.90 \pm 0.07 & -1.07 \pm 0.28^{*} & 0.86 \pm 0.30 & -0.30 \pm 0.30\end{array}$

${ }_{* * *}^{*} P<0.001 ; * * 0<0.01 ;{ }^{*} P<0.05 ;$ ns: non-significant.

Rogers's random predator equation was used to septempunctata providing estimates of both search describe type II functional response of larval $C$. rate (a) and handling time $\left(\mathrm{T}_{\mathrm{h}}\right)$. The handling time March 2021 | Volume 37 | Issue 1 | Page 230 
and searching efficacy values for larval beetle are presented in Table 3.

Table 3: Parameters for type of functional response models for larvae of $C$. septempunctata at $L C_{30}$.

$\begin{array}{llllll}\text { Treatment } & \text { Type } & \mathbf{A} & \mathbf{T}_{\mathbf{h}} & \mathbf{T}_{\mathbf{T}} \mathbf{T}_{\mathbf{h}} & \mathbf{R}^{\mathbf{2}} \\ \text { Control } & \text { II } & 0.170 & 0.16 & 150.00 & 0.99 \\ \text { Imidaclorpid } & \text { III } & 0.02 & 0.26 & 92.30 & 0.96 \\ \text { Thiamethoxam } & \text { II } & 0.01 & 0.33 & 72.72 & 0.96 \\ \text { Profenophos } & \text { III } & 0.015 & 0.53 & 45.28 & 0.96 \\ \text { Chlorpyrifos } & \text { III } & 0.011 & 0.29 & 82.75 & 0.96 \\ \text { Lambda-cyhalothrin } & \text { II } & 0.021 & 0.50 & 48.00 & 0.89 \\ \text { Cypermethrin } & \text { II } & 0.031 & 0.74 & 32.43 & 0.85\end{array}$

A: attack rate; Th: handling time; T/Th: attack rate.

The larval beetles have higher attack rate $(0.17)$ in control as compared to sublethal concentration of thiamethoxam, lambda-cyhalothrin and cypermethrin with Type II functional response. The handling time $\left(\mathrm{T}_{\mathrm{h}}\right)$ of adults after feeding on insecticide treated aphids was longer compared to control treatment. The control treatment was having the $T_{h} 0.16$ hours. Among the insecticides used, cypermethrin has maximum $T_{h}(0.74 h)$ followed by profenophos (0.53h), lambda-cyhalothrin $(0.50 \mathrm{~h})$, thiamethoxam (0.33h), chlorpyrifos (0.29) and imidacloprid (0.26h). As the rate of predation $\left(\mathrm{T} / \mathrm{T}_{\mathrm{h}}\right)$ depends on handling time, likewise, rate of predation was highest in control beetles followed by imidacloprid, chlorpyrifos, thiamethoxam, lambda-cyhalothrin, profenophos and cypermethrin (Table 3 ). The two parameters, $\mathrm{T}_{\mathrm{h}}$ and $\mathrm{T} / \mathrm{T}_{\mathrm{h}}$, are inversely proportional to each other. It is obvious from the table that, overall, the coccinellid larvae showed higher attack (A) on aphids in control as compared to insecticide treated aphids. Larvae have least $T_{h}$ and highest $T / T_{h}$ in control. For functional response III the parameters $\mathrm{c}$ and $\mathrm{d}$ of non-linear least square regression were not significantly different from zero (data not presented here) and we eliminated them from model and used the reduced model.

The functional response type II and III are very important because most of the natural enemies show such type of responses. The functional response can determine How the predator regulates the host populations, is determined by functional response (Murdoch and Oaten, 1975). Therefore, our study evaluated the effects of six insecticides on $C$. septempunctata functional response keeping in view the importance of type of functional response. Our results have revealed that the application of sublethal concentration of imidacloprid, profenophos and chlorpyrifos changed the functional response of larvae from type II to III. Sublethal concentrations of insecticides also increased the prey handling time and decreased the maximum attack rate of coccinellids. It is likely that the change in behavior and functional response of adult and larval coccinellids might be due to the unconsciousness and disorientation induced by the insecticides targeting insect nervous system. Our results are in agreement with Claver et al. (2003), Ambrose et al. (2010), Rezaei et al. (2014) and Faal-Muhammad-Ali et al. (2015). It is concluded that the three insecticides (thiamethoxam, lambdacyhalothrin and cypermethrin) did not change the functional response of larval coccinellids. While these insecticides increased the handling time and decreased the maximum attack rate relative to control. It is likely that these insecticides are relatively safe for larval coccinellids.

\section{Conclusions and Recommendations}

Based on overall results, it is concluded that all insecticides significantly affected the biological parameters. Type II response was shown by the larvae of $C$. septempunctata in control treatment. Imidacloprid, profenophos and chlorpyrifos altered the functional response of larval coccinellids from II to III. Conclusively, none of the insecticides was found safe and all insecticides have adverse effect on life parameters of coccinellids. As thiamethoxam, cypermethrin and lambda-cyhalothrin did not change the functional response of larval coccinellids, so these insecticides were considered safe for coccinellids hence recommended for aphid control.

\section{Acknowledgements}

This research work was supported by the Department of Entomology, College of Agriculture, University of Sargodha, Sargodha, Pakistan. Authors are thankful to Dr. Abu Bakar M. Raza, for his valuable comments and proof-reading of the manuscript.

\section{Novelty Statement}

The research work highlights the significance of sublethal doses of insecticides and their impact on the life parameters and functional response of coccinellids beetles. 


\section{Author's Contribution}

MAR conceived the idea and MA helped to plan the experiment and performed statistical analyses and technically revised the manuscript. RA and MZM performed bioassay experiments. MA revised and improved the manuscript. MAR supervised the research and technically proof-read the manuscript.

\section{Conflict of interest}

The authors have declared no conflict of interest.

\section{References}

Ambrose, D., S. Rajan and J. Raja. 2010. Impacts of synergy-505 on the functional response and behavior of the reduviid bug, Rhynocoris marginatus. J. Insect Sci., 10: 187. https://doi. org/10.1673/031.010.18701

Booth, L.H., S.D. Wratten and P. Kehrli, 2007. Effects of reduced rates of two insecticides on enzyme activity and mortality of an aphid and its lacewing predator. J. Econ. Entomol., 100: 11-19.

Bozsik, A., 2006. Susceptibility of adult Coccinella septempunctata (Coleoptera: Coccinellidae) to insecticides with different modes of action. Pest Manage. Sci., 62: 651-654. https://doi. org/10.1002/ps.1221

Capowiez, Y. and C. Bérard. 2006. Assessment of the effects of imidacloprid on the behavior of two earthworm species (Aporrectodea nocturna and Allolobophora icterica) using 2D terraria. Ecotoxicol. Environ. Saf., 64: 198-206. https://doi.org/10.1016/j.ecoenv.2005.02.013

Claver, M., B. Ravichandran, M. Khan and D. Ambrose. 2003. Impact of cypermethrin on the functional response, predatory and mating behaviour of a non-target potential biological control agent Acanthaspis pedestris (Stål) (Het., Reduviidae). J. Appl. Entomol., 127: 18-22. https://doi.org/10.1046/j.14390418.2003.00654.x

Debach, P. and D. Rosen. 1991. Biological control by natural enemies. CUP Archive. Cambridge University Press, New York. pp. 1-440.

Desneux, N., A. Decourtye and J. Delpuech. 2007. The sublethal effects of pesticides on beneficial arthropods. Annu. Rev. Entomol., 52: 81-106. https://doi.org/10.1146/annurev. ento.52.110405.091440
Desneux, N., X. Fauvergue, F.X. DechaumeMoncharmont, L. Kerhoas, Y. Ballanger and L. Kaiser. 2005. Diaeretiella rapae Limits Myzus persicae populations following applications of deltamethrin in oilseed rape. J. Econ. Entomol., 98: 9-17. https://doi.org/10.1093/jee/98.1.9

Dolling, W.R., 1991. The Hemiptera. Oxford University Press, Oxford, pp. 1- 274.

Faal-Muhammad-Ali, H., H. Allahyari and M. Saber. 2015. Sublethal effect of chlorpyriphos and fenpropathrin on functional response of Habrobracon hebetor (Hym.: Braconidae). Arch. Phytopathol. Plant Protect., 48: 288-296. https://doi.org/10.1080/03235408.2014.8864 11

Farooq, A. and Z. Tasawar. 2008. Evaluation of integrated management of aphid pests, Brevicoryne Brassicae and Lipaphis Erysimi on canola crop in southern Punjab, Pakistan. Pak. J. Zool., 40(1): 13-17.

Fernandes, M.E., F.M. Alves, R.C. Pereira, L.A. Aquino, F.L. Fernandes, J.C. Zanuncio. 2016. Lethal and sublethal effects of seven insecticides on three beneficial insects in laboratory assays and field trials. Chemosphere, 156: 45-55. https://doi.org/10.1016/j. chemosphere.2016.04.115

Galvan, T.L., R.L. Koch and W.D. Hutchison. 2005. Effects of spinosad and indoxacarb on survival, development, and reproduction of the multicolored Asian lady beetle (Coleoptera: Coccinellidae).Biol.Contr.,34:108-114.https:// doi.org/10.1016/j.biocontrol.2005.04.005

Hardin, M.R., B. Benrey, M. Coll, W.O. Lamp, G.K. Roderick and P. Barbosa. 1995. Arthropod pest resurgence: An overview of potential mechanisms. Crop Prot., 14: 3-18. https://doi. org/10.1016/0261-2194(95)91106-P

Holling, C.S., 1965. The functional response of predators to prey density and its role in mimicry and population regulation. Mem. Entomol. Soc. Can., 97: 5-60. https://doi.org/10.4039/ entm9745fv

James, D.G., 2002. Fecundity in two spotted spider mite (Acari: Tetranychidae) is increased by direct and systemic exposure to imidacloprid. J. Econ. Entomol., 95: 729-732. https://doi. org/10.1603/0022-0493-95.4.729

Juliano, S.A., 2001. Nonlinear curve fitting: predation and functional response curves. In: Schiner S.M., Gurevitch J. (eds): Design and 
analysis of ecological experiments. $2^{\text {nd }} \mathrm{Ed}$. Chapman and Hall, New York. pp. 178-196.

Khan, S.M. and H.A. Begum. 2005. Chemical control of canola aphid Lipaphis erysimi Kalt (Aphididae: Homoptera). Pak. Entomol., 27: 29-35.

Lanzoni, A., L. Sangiorgi, V. D. Luigi, L. Consolini, E. Pasqualini and G. Burgio. 2012. Evaluation of chronic toxicity of four neonicotinoids to Adalia bipunctata L. (Coleoptera: Coccinellidae) using a demographic approach. IOBC/ WPRS Bull., 74: 211-217.

Martinou, A.F. and M.C. Stavrinides. 2015. Effects of sub-lethal concentrations of insecticides on the functional response of two Mirid generalist predators. PLoS One, 10: 144-413. https://doi. org/10.1371/journal.pone.0144413

Murdoch, W.W. and A. Oaten. 1975. Predation and population stability. Adv. Ecol. Res., 9: 1-125. https://doi.org/10.1016/S00652504(08)60288-3

Murdoch, W.W., C.J. Briggs, R.M. Nisbet. 2003. Consumer-resource dynamics Princeton, NJ: Princeton University Press. Princeton, New Jersey, USA. https://doi. org/10.1515/9781400847259

Newsom, L.D., 1974. Predator insecticide relationship. Entomophaga Memoirs. HorsSer., 7: 13-23.

Pasqualini, E. and S. Civolani. 2003. Studies on side effects of some insecticides on aphid-feeding Coccinellidae in Emilia-Romagna fruit crops. Pesticides and Beneficial Organisms IOBC/ wprs Bull., 26: $51-55$.

Rahmani, S. and A.R. Bandani. 2013. Sublethal concentrations of thiamethoxam adversely affect life table parameters of the aphid predator, Hippodamia variegata (Goeze) (Coleoptera: Coccinellidae). Crop Prot., 54: 168-175. https://doi.org/10.1016/j.cropro.2013.08.002

Rezaei, N., F. Kocheyli, M.S. Mossadegh, K.T. Jahromi, A. Kavousi. 2014. Effect of sublethal doses of thiamethoxam and pirimicarb on functional response of Diaeretiella rapae (Hymenoptera: Braconidae), parasitoid of Lipaphis erysimi (Hemiptera: Aphididae). J. Crop Prot., 3: 467-477.

Rogers, D.J., 1972. Random search and insect population models. J. Anim. Ecol., 41: 369-383. https://doi.org/10.2307/3474

Saljoqi, A.U.R., R. Zada, I. Munir, R. Sadur and
H.J.A. Khan. 2012. Population trend of canola aphid, Lipaphis erysimi (Kalt.) (Homoptera: Aphididae) and its associated natural enemies in different Brassica lines along with the effect of gamma radiation on their population. Pak. J. Zool., 44: 1051-1057.

Sechser, B., S. Ayoub and N. Monuir. 2003. Selectivity of emamectin benzoate to predators of sucking pests on cotton. J. Plant. Dis. Prot., 110: 184-194.

Stark, J.D., R.I. Vargas and J.E. Bank. 2007. Incorporating ecologically relevant measures of pesticide effect for estimating the compatibility of pesticides and biocontrol agents. J. Econ. Entomol., 100: 1027-1032. https://doi. org/10.1093/jee/100.4.1027

Sunday, O.O., L. Akinwande Kayode, M. Ashamo. 2016. Laboratory review of sublethal effects of cypermethrin on oviposition, life span and egg development in Culex quinquefasciatus, Say (Diptera: Culicidae). Int. J. Mosquito Res., 3: 20-25.

Tabozada, E.O., S.M. Sayed and S. El-Arnaouty. 2015. Side effects of sub-lethal concentration of two Neonicotinoids; Thiamethoxam and Thiacloprid on the larval parasitoid, Bracon brevicornis (Hymenoptera: Braconidae). Am. J. Exp. Agric., 5: 29. https://doi.org/10.9734/ AJEA/2015/12469

Tillman, P.G. and J.E. Mulrooney. 2000. Effect of selected insecticides on the natural enemies Colleomegilla maculata and Hippodamia convergens (Coccinellidae), Geocoris punctipes (Lygaeidae), and Bracon mellitor, Cardiochiles nigriceps, and Cotesia marginiventris (Braconidae) in cotton. J. Econ. Entomol., 93: 1638-1643. https://doi.org/10.1603/00220493-93.6.1638

Widiarta, N., M. Matsumura, Y. Suzuki and F. Nakasuji. 2001. Effects of sublethal doses of imidacloprid on the fecundity of green leafhoppers, Nephotettix spp. (Hemiptera: Cicadellidae) and their natural enemies. Appl. Entomol. Zool., 36: 501-507. https://doi. org/10.1303/aez.2001.501

Yadav, S. and M. Rathee. 2020. Sucking pests of rapeseed-mustard. In: Sucking Pests of Crops. Springer, Singapore. pp. 187-232. https://doi. org/10.1007/978-981-15-6149-8_6

Youn, Y.N., M.J. Seo, J.G. Shin, C. Jang and Y.M. Yu. 2003. Toxicity of greenhouse pesticides 
to multicolored Asian lady beetles, Harmonia axyridis (Coleoptera: Coccinellidae). Biol. Contr., 28: 164-170. https://doi.org/10.1016/ S1049-9644(03)00098-7

Yu, C., M. Fu, R. Lin, Y. Zhang, L. Yongquan, H. Jiang and T.C.M. Brock. 2014. Toxic effects of hexaflumuron on the development of Coccinella septempunctata. Environ. Sci. Pollut. Res. Int., 21(2): 1418-1424. https://doi.org/10.1007/ s11356-013-2036-8

Zarghami, S., M.S. Mossadegh, F. Kocheili, H. Allahyari and A. Rasekh. 2016. Functional responses of Nephus arcuatus Kapur (Coleoptera: Coccinellidae), the most important predator of spherical mealybug Nipaecoccus viridis (Newstead). Psyche, pp. 1-9. https://doi. org/10.1155/2016/9417496

Zhang, D.W., M. Dong., X.G. Du. 2011. Effects of organic management on predator densities of Myzus persicae (Sulzer) during transition to organic agriculture in peach fields in China. J. Sustain. Agric., 35: 826-839. https://doi.org/1 0.1080/10440046.2011.588997 